\title{
Pastorałka dramatyczna Juliusza Słowackiego i jej muzyczna interpretacja we Fragmentach Zygmunta Mycielskiego
}

DOI: $10.14746 / \mathrm{rfn} .2020 .21 .2$

I. Jak przekonywała Agata Seweryn, twórczość jednego z ulubionych romantyków Karola Wojtyły - Juliusza Słowackiego, w tym „nutami niesiona”" poezja, wielokrotnie inspirowała polskich kompozytorów. Choć sytuacja społeczno-polityczna naszego kraju w wieku XIX oraz na przełomie XIX i XX stulecia wpłynęła na ograniczoną recepcję idei Wagnerowskiego dramatu muzycznego, przez co brakowało odpowiedniego gatunku, który mógłby udźwignąć spuściznę dramatyczną Słowackiego, to jego twórczość swą potencjalną muzycznością literacką ${ }^{2}$ otwierała się na kompozytorskie interpretacje. Wymienić można szereg utworów nawiązujących do wątków pochodzących z dzieł autora Kordiana. Do tekstów poetyckich Juliusza Słowackiego powstawały bowiem pieśni solowe i utwory chóralne, na grunt muzyki operowej adaptowano

\footnotetext{
1 Por. A. Seweryn, Poezja „nutami niesiona”. O muzycznej recepcji twórczości Juliusza Stowackiego, Warszawa 2008.

2 „Słowacki w przeciwieństwie do Mickiewicza i Krasińskiego tworzył stosunkowo bardzo niewiele utworów lirycznych, odpowiednich dla techniki kompozytorskiej, właściwej liryce muzycznej, wiersz zaś jego tchnący pierwiastkiem muzycznym, posiada cechy niedogodne dla wokalizmu muzycznego, zawiera bowiem stosunkowo niewiele samogłosek podatnych dla wymowy w śpiewie. Oczywiście to samo odnosi się do tekstów dramatycznych Słowackiego. [...] wiersz Słowackiego nie znosi uzupełniania go muzyką, jako mający w sobie tyle muzycznego (w literackim tego słowa znaczeniu) pierwiastka”; A. Chybiński, Juliusz Słowacki w muzyce polskiej, „Pamiętnik Literacki" 1909 t. 8 nr 1/4, s. 225-227.
}

dramaty i poematy, jego poezja inspirowała gatunki kantatowo-oratoryjne oraz twórczość programową. Zakres liryki wokalnej inspirowanej poezją Juliusza Słowackiego współtworzą następujące pieśni i cykle: Skad pierwsze gwiazdy Mieczysława Karłowicza (1896), Dwie pieśni op. 139 Apolinarego Szeluty (1949), Trzy pieśni op. 3 (1956) i Śpiewy op. 48 (1983) Henryka Mikołaja Góreckiego oraz pozostające w rękopisach miniatury wokalne Witolda Friemanna i Jana Adama Maklakiewicza. Z kręgu literatury chóralnej wymienić można Dumę ukrainską Henryka Jareckiego (1875), 2 kolędy Kazimierza Wiłkomirskiego (1947) oraz 8 pieśni na chór mieszany Henryka Swolkienia (1959). Dzieła sceniczne stworzyli: Henryk Jarecki (Mindowe, 1880), Władysław Żeleński (Goplana, 1896), Adam Münchheimer (Mazepa, 1900) i Ludomir Różycki (Beatrix Cenci, 1925-1926); kantatowo-oratoryjne: Tadeusz Szeligowski (Rapsod, 1949), Andrzej Krzanowski (Audycja VI, 1982), Roman Palester (Listy do Matki, 1984-1987) i Zygmunt Mycielski (Fragmenty, 1987). Zestawienie to domykają utwory programowe: Lilla Weneda Henryka Opieńskiego (1908-1909), Anhelli Ludomira Różyckiego (1909) oraz Pożegnanie Ellenai Feliksa Nowowiejskiego (1914).

II. W powyższym wykazie znajduje się ostatnia kompozycja Zygmunta Mycielskiego, ukończone 
9 kwietnia 1987 roku Fragmenty na chór i małą orkiestrę, dopełniające stosunkowo skromną listę religijnych utworów autora Postludiów. Oficjalnie wymienia się bowiem - obok Fragmentów - Trzy psalmy (1982-1983) i mszę Liturgia sacra (1983-1984), wspominając o kameralnym Fiat voluntas tua (1943) oraz okolicznościowej miniaturze chóralnej Wieczne odpoczywanie (1983-1984).

Pisane w niemieckim obozie jenieckim offertorium Fiat voluntas tua, które miało być wykorzystane jako oprawa muzyczna mszy wielkanocnej w kwietniu 1943 roku, wyraźnie inspirowane jest muzyką Jana Sebastiana Bacha ${ }^{3}$ (aczkolwiek kompozytor wyznawał na stronie tytułowej, iż nie był w stanie przypomnieć sobie wówczas chorałów z Orgelbüchlein; por. fot. 1). Okoliczności powstania Fiat... z pewnością przyczyniły się do ograniczenia środków wykonawczych do obsady kameralnej, zastosowania stosunkowo prostej faktury (dialogowanie, prowadzenie linii melodycznej $\mathrm{w}$ równoległych tercjach i sekstach) oraz tradycyjnych rozwiązań tonalno-harmonicznych. Jest to jedyna ukończona kompozycja religijna Zygmunta Mycielskiego powstała przed wyraźnym zwrotem twórcy ku najważniejszym tekstom chrześcijaństwa, jaki miał miejsce w ostatnich latach jego życia.

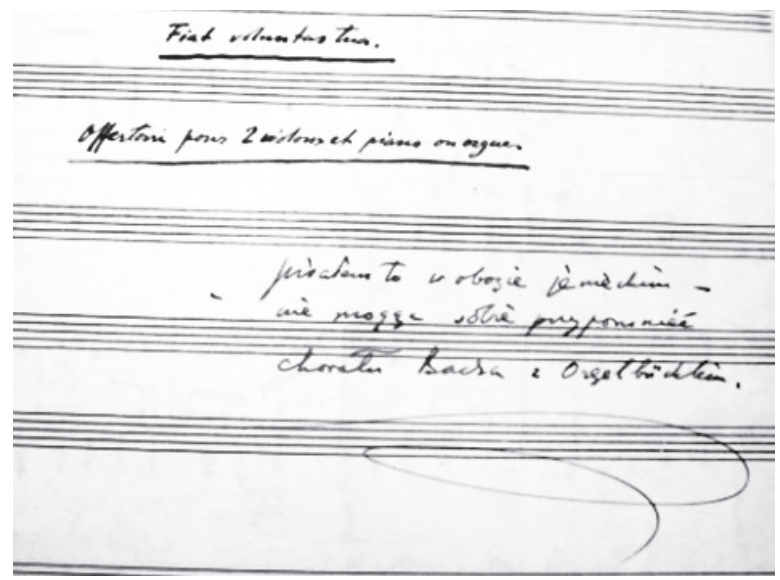

Fot. 1. Zygmunt Mycielski, Fiat voluntas tua na dwoje skrzypiec i fortepian lub organy, strona tytułowa

3 Por. B. Mielcarek-Krzyżanowska, „U Bacha ani jedna nuta nie spada z nieba”. Zygmunt Mycielski a twórczość Jana Sebastiana Bacha, [w:] Dzieło muzyczne wobec przeszłości i współczesności, red. A. Nowak i B. Mielcarek-Krzyżanowska, Bydgoszcz 2020, s. 317-318.
Kiedy jako dojrzały kompozytor, z teką wypełnioną przede wszystkim symfoniami i pieśniami (stanowiącymi trzon jego twórczości), zapisał na kartach nibydziennika „Bóg musi być”" , skierował swą uwagę na naznaczone duchowością judeochrześcijańską utwory większych rozmiarów. Powstały wówczas Trzy psalmy oraz Liturgia sacra, które interpretować można jako wyznanie wiary Mycielskiego, powtarzającego wielokrotnie na kolejnych stronicach mszy Credo..., credo... [wierzę] oraz Domine, non sum dignus... [Panie, nie jestem godzien...]. Ostatnie miesiące życia wypełniło mu opracowanie kilku wersów tekstu bożonarodzeniowego misterium Juliusza Słowackiego, zatytułowanych w wersji słowno-muzycznej - Fragmenty. Kompozycje te: Trzy psalmy, Liturgia sacra oraz Fragmenty, dostrzeżone i pozytywnie przyjęte przez krytykę (wcześniej raczej chłodno reagującą na stosunkowo rzadkie wykonania utworów Mycielskiego), przyniosły kompozytorowi rodzaj wewnętrznego ukojenia, upewnienia co do słuszności podjętych decyzji twórczych.

$\mathrm{Z}$ tego okresu pochodzi także niewielkich rozmiarów Wieczne odpoczywanie napisane dla chóru z rodzinnej Wiśniowej, kompozycja, która zabrzmiała w czasie uroczystości pogrzebowych Zygmunta Mycielskiego.

Uzupełnienie powyższego zestawienia umożliwia ponadto przeprowadzona przez autorkę niniejszego tekstu kwerenda Archiwum Zygmunta Mycielskiego znajdującego się w zbiorach Zakładu Rękopisów Biblioteki Narodowej w Warszawie. Wykaz religijnych kompozycji poszerzyć można o trzy znaczące, jak się wydaje, szkice: młodzieńczy Psalm XXVIII (sprzed 1939 roku) oraz dwa utwory o charakterze oratoryjnym: Charitas do tekstu moralitetu/dramatu Miłosierdzie Karola Huberta Rostworowskiego (1969) i Lignum vitae (inny tytuł Raj utracony) na podstawie Księgi Rodzaju (1973).

III. Przywołane kompozycje, wraz z opracowanymi na orkiestrę symfoniczną preludiami chorałowymi Jana Sebastiana Bacha (1964), stanowią przeciwwagę dla sądów wypowiadanych przez Barbarę Gutkowską, badaczkę XX-wiecznych autobiografii, jakoby Zygmunt

4 „Pan Bóg musi być!” Cyt. za: Z. Mycielski, Niby-dziennik ostatni 1981-1987, Warszawa 2012, s. 316 (zapis z 9 VII 1983). 
Mycielski był ateistą ${ }^{5}$. Choć z kart jego dzienników przebija niekiedy rozczarowanie i zwątpienie ${ }^{6}$, odnosi się często wrażenie, że kompozytor traktował swą duchowość jako wyjątkową sferę prywatności, strzegąc jej przed próbami jednoznacznych klasyfikacji. Co więcej, rozpatrywanie konfesyjności Mycielskiego wyłącznie przez pryzmat dzienników (w ostatnich latach życia wyraźnie rozjaśnionych wyznaniem „Pan Bóg musi być!"”), bez uwzględnienia twórczości artystycznej, która była dlań niezwykle istotną formą wypowiedzi, prowadzi do niepełnych wyobrażeń o jego światopoglądzie. W różnych momentach życia, nie tylko w obliczu cierpień, pojawiały się u autora Dzienników przebłyski tęsknoty za Bytem wyższym. Potwierdzeniem tej tezy może być zapis z 1957 roku, w którym twórca odwołał się do wyniesionego $\mathrm{z}$ domu rodzinnego duchowego fundamentu:

Gdybym nie miał „spodu” i formacji chrześcijańskiej i dosyć rozwiniętej znajomości zasad chrześcijańskich i katolickich, to - z umysłem i uczuciowością, jaką mam, z wizją świata taką, jaką mam - mógłbym się tylko powiesić. Tylko ten „spód” tej formacji pozwala mi żyć, nawet „nie wierząc”. Bo daje mi pojęcie jakiejś ofiary, pojęcia wartości, które choć mogą nie mieć dla mnie znaczenia prawdy absolutnej to jednak dają mi nadzieję, że istnieją, choćby tylko jako pojęcia $^{8}$.

5 „[...] Mycielski, zadeklarowany ateista, w sztuce uparcie i z rozmysłem szukał Absolutu, Sensu, będącego gwarantem człowieczeństwa, hierarchii, ładu, bez których świat pogrąża się w bezrozumnym zamęcie”; por. B. Gutkowska, „Chciałbym jeszcze kogoś uzdrowić, coś uzdrowić, naprawić. Ale jest już za późno". Fenomen dzienników Zygmunta Mycielskiego, [w:] Człowiek, myśl, muzyka. Wokół postaci i twórczości Zygmunta Mycielskiego, red. B. Bolesławska-Lewandowska, B. Mielcarek-Krzyżanowska, G. Oliwa, Rzeszów 2019, s. 27.

6 Wątek ten podnosi także Anna Koszewska, piszac: „na kartach dziennika problem istnienia Boga - wyrażany nieraz jako zwątpienie czy nawet zanegowanie jego czynnej obecności w świecie - przewija się niczym leitmotiv, jest wszechobecny. [...] Nie sposób jednak przejść obojętnie nad refleksją Mycielskiego wpisaną do dziennika po lekturze pism św. Teresy z Avila: «Cała sztuka jest tylko modlitwą. Do czegoś, do kogoś, a gdy już nie ma niczego, ani nikogo, to do siebie, do własnych możliwości, które pragną wyrazić głęboko ukrytą tęsknotę za lepszym i piękniejszym światem»"; por. A. Koszewska, Credo estetyczne Zygmunta Mycielskiego. Próba rekonstrukcji systemu, [w:] Krytyka muzyczna. Teoria, historia, współczesność, red. M. Bristiger, R. Ciesielski, B. Literska, J. Guzy-Pasiak, Zielona Góra 2009, s. 180.

7 Cyt. za: Z. Mycielski, Niby-dziennik ostatni..., op. cit., s. 316 (zapis z 9 VII 1983)

8 Cyt. za: Z. Mycielski, Dziennik 1950-1959, Warszawa 1999, s. 274-275 (zapis z 14 IV 1957).
Podobne intuicje odnalazła w piśmiennictwie Mycielskiego Anna Koszewska, wyróżniając passus zamieszczony na łamach Szkiców i wspomnień twórcy Fragmentów: „[...] religia i sztuka mówią o czymś więcej, bo o naszej roli na ziemi. Czyli o najważniejszej sprawie, jaką umysł ludzki zrodził”'. Podkreślając w swych rozważaniach owo szczególne zestrojenie sztuki i religii, konstatowała: „Muzyka stała się wiarą w twórczym, życiowym obrachunku Zygmunta Mycielskiego. Albo też - być może - wiara religijna zawarła się w muzyce"10.

Jak założyć można na podstawie odnalezionych szkiców, powstająca na przestrzeni wielu lat, a nie - jak do niedawna sądzono - w ostatnim okresie życia, twórczość religijna Zygmunta Mycielskiego przypuszczalnie zaspokajała jego głęboką potrzebę metafizyki. Kompozytor sięgał do znanych mu od najmłodszych lat różnorodnych fragmentów z $P i-$ sma Świętego, do tekstów ordinarium i proprium oraz wybranych dzieł literackich, wykorzystując je niekiedy w funkcji inspirujących, znaczących tytułów (np. Fiat voluntas tua w instrumentalnym offertorium), najczęściej zaś jako element powstającej złożonej słowno-muzycznej struktury w utworach wokalno-instrumentalnych.

IV. Choć w szczególny sposób ostatni z dzienników Mycielskiego ${ }^{11}$ odsłania przed czytelnikami różnorodne dylematy towarzyszące procesowi twórczemu (wskazuje teksty poetyckie poddawane opracowaniom, zatrzymuje się nad ich fragmentami interpretując je w szerokim kontekście kulturowym, dokonuje wyboru materiału dźwiękowego, szkicuje motywy dopisując komentarze o planowanych zamierzeniach kompozytorskich, ogólnie odnosi się do sposobu kształtowania dramaturgii kolejnych ogniw powstających utworów), w odniesieniu do Fragmentów do słów Juliusza Słowackiego twórca nie ujawnił źródeł swych fascynacji. Hipotetycznie wskazać można zarówno jego rozległe zainteresowania i erudycję, jak też spotkania z księdzem Janem Twardowskim, który patronował powstaniu Trzech psalmów i Liturgiae sacrae, a być może podsunął także kompozytorowi

9 Cyt. za: Z. Mycielski, Szkice i wspomnienia, Warszawa 1999, s. 230 .

10 A. Koszewska, Credo estetyczne ..., op. cit., s. 180.

11 Z. Mycielski, Niby-dziennik ostatni..., op. cit. 
tekst Góry się ozłociły... W rozmowie z prezesem Towarzystwa im. Zygmunta Mycielskiego, Andrzejem Szypułą, twórca Litanii polskiej wyznał:

Miałem z Nim [Mycielskim] miłe spotkania. Wspólnie zastanawialiśmy się nad tekstami liturgicznymi, łacińskimi, które wykorzystywał On do swoich dzieł. Pomagałem w ich wyborze. Odwiedzałem Go w szpitalu, kiedy był już bardzo chory $^{12}$.

Pierwszą stronę notatnika obejmującego okres 26 sierpnia 1984-3 lutego 1986 otwiera zapis fragmentu utworu poetyckiego Juliusza Słowackiego:

Góry się ozłociły - szafiry mórz ciemnieją.

Fale wstały. Od ziemi wiatr i koguty pieją.

Miesiąc jak ogień stoi na czarnym oceanie.

Korab na dalekościach wre na rozognionej pijanie.

Korab, wieloryb świata, z ogniami w okiennicach

Ku niemu idą Boże obłoki całe w świécach.

Uciszyło się morze i ziemia, i powietrze.

Wstawaj! Z pieśniami idźmy pasterskimi

Pozdrowić dziecko... świat cały w rozruchu.

Zagroda w ogniu - trzody nasze w duchu,

Psy drżą... i siedzą z oczyma złotymi,

Podnosząc w górę nastrzyżone słuchy.

Pan przyszedł: wdziejmy baranie kożuchy

I chodźmy - ranni ludzie z pozdrowieniem.

Powyższy fragment, będący częścią większego utworu Słowackiego powstałego prawdopodobnie w styczniu 1843 roku, do chwili obecnej nie zyskał jednoznacznej kwalifikacji gatunkowej - zamieszczany bywał wśród wierszy ${ }^{13}$, poematów ${ }^{14}$, określano go jako „oratorium mistyczne” ${ }^{15}$, „misterium Bożonarodzeniowe" ${ }^{16}$, a także - kierując uwagę w stronę

${ }^{12}$ Cyt. za: Człowiek nigdy nie jest sam. Rozmowa z ks. Janem Twardowskim w Warszawie (rozmawiał Andrzej Szypuła), „Kamerton" 1993 t. 3(14), s. 23.

${ }_{13}$ Por. M. Ławrynkowicz, Nowe wydanie krytyczne Poematów Juliusza Słowackiego, „Sztuka Edycji” 2011 t. 1, s. 90.

${ }^{14}$ B. Gubrynowicz, Z nieznanych rękopisów po Stowackim, „Pamiętnik Literacki” 1909 t. 8 nr 1/4, s. 236.

${ }_{15}$ Opinia prof. Tretiaka przywołana przez Bronisława Gubrynowicza; $Z$ nieznanych rękopisów po Stowackim..., op. cit., s. 236.

${ }^{16}$ L. Zwierzyński, Egzystencja i eschatologia. Genezyjska wyobraźnia Słowackiego, Katowice 2008, s. 292. towianizmu - jako „misterjum o narodzeniu Sprawy Bożej”'17. Z kolei uwzględniając konstrukcję tekstu i sposób prezentacji treści (części dialogowane stanowiące ramę dla środkowej parabazy ${ }^{18}$ ) nazywano go także tryptykiem ${ }^{19}$.

Wybrany przez Mycielskiego środkowy fragment wiersza-poematu-misterium nabiera charakteru pastorałki. Choć brak w tekście Słowackiego obrazu stajenki i typowych dla bożonarodzeniowych sielanek scen adoracji, wyszukanymi środkami stylistycznymi - hiperbolicznymi tropami ${ }^{20}$ - nakreślił poeta nieziemską aurę towarzyszącą Tajemnicy Narodzenia, m.in. przeobrażając blask stajenki w ogień rozświetlający noc.

V. Przystępując do opracowania tekstu, kompozytor sięgnął do techniki wypracowanej w latach 1957-1960, określonej przez Iwonę Lindstedt ${ }^{21}$ jako system tablicowy (tzw. matrix system oraz board system). Technika ta okazała się na tyle uniwersalna, że pozwoliła Mycielskiemu na realizację różnorodnych gatunków instrumentalnych i wokalno-instrumentalnych. Wypracowywanie tego systemu wiązało się z przemianami roku 1956. Próbując w okresie odwilży w polskiej kulturze znaleźć adekwatne do zmieniającej się wyobraźni dźwiękowejej środki wyrazu, badając możliwości dodekafonii i serializmu, wypracował indywidualny sposób komponowania za pomocą dwunastu dźwięków. Stosując procedury bliskie serializmowi, zaczął konstruować szeregi 12-dźwiękowe oraz wskazywał możliwości ich permutacji grupując je w tablice nazywane przezeń

17 Do tekstu Pigonia (Misterjum o narodzeniu Sprawy Bożej, „Pamiętnik Literacki” 1916) odsyła Stefania Bilińska w pracy Chrystus $i$ chrześcijaństwo $w$ twórczości Słowackiego epoki mistycznej, Tarnów 1929.

18 Por. S. Pigoń, Nowe wydanie zbiorowe Stowackiego, „Pamiętnik Literacki" 1950 t. 39, s. 370

19 Por. ibidem.

20 Por. komentarz Jana Okonia do antologii Staropolskie pastoratki dramatyczne, Wrocław 1989, s. LXX.

${ }^{21}$ I. Lindstedt, Dodekafonia i serializm w twórczości kompozytorów polskich XX wieku, Lublin 2001.

${ }_{22}$ Por. fragment listu do Andrzeja Panufnika z dnia 26 XII 1957: „[...] chcę napisać coś, co dla mnie będzie zupełnie nowe. Us zy $\mathrm{mi}$ się bardzo zmieniły [rozstrzelenie - BMK]". Cyt. za: Zygmunt Mycielski - Andrzej Panufnik. Korespondencja. Część I: lata 19491969, opracowanie, wstęp i komentarze B. Bolesławska-Lewandowska, Warszawa 2017, s. 42. 
dodekafonicznymi ${ }^{23}$. Poza zewnętrznym podobieństwem i nazewnictwem (seria, szereg, permutacja etc.) nie miały one punktów stycznych $\mathrm{z}$ tradycją wiedeńską - bliższe były teorii Herberta Eimerta ${ }^{24}$. Zakładał bowiem Mycielski możliwość dowolnego operowania wycinkami szeregu, powtarzalność dźwięków, wprowadzanie następstw sekundowych i tercjowych oraz współbrzmień (np. kwintowych i oktawowych) kojarzonych $\mathrm{z}$ systemem modalnym oraz systemem tonalnym dur-moll. Wypracowana metoda, zastosowana po raz pierwszy w II Symfonii (powstałej na materiale Wariacji matematycznych na orkiestrę, które chciał Mycielski zadedykować Nadii Boulanger ${ }^{25}$ ), sprowadzająca się do podporządkowania procedur prekompozycyjnych („spekulacji”) kategoriom emocjonalnym („wzruszeniom”), stała się swoistym modus operandi następnych kompozycji, w tym także ostatnich Fragmentów.

Szereg dźwiękowy będący podstawą materiałową Fragmentów do słów Juliusza Słowackiego eksponuje $\mathrm{w}$ szczególny sposób brzmienie czystych kwart i - odpowiednio w inwersji - czystych kwint (por. fot. 2).

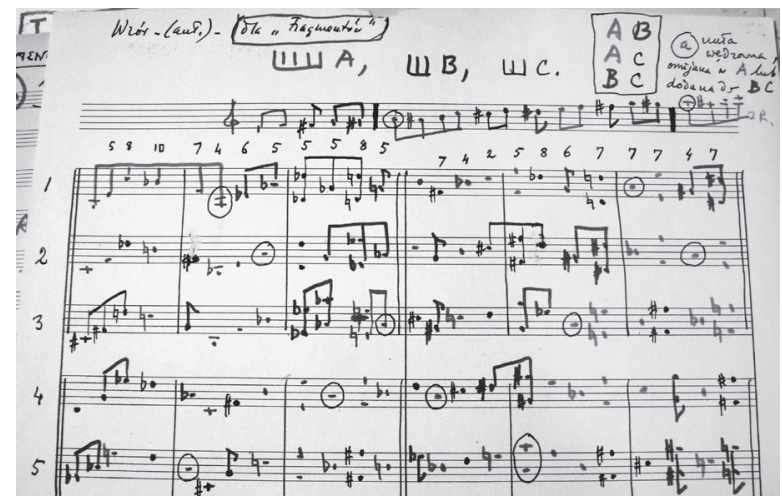

Fot. 2. Zygmunt Mycielski, tablice dodekafoniczne do Fragmentów (wycinek)

${ }^{23}$ Por. Z. Mycielski, Jeszcze o wyborach wysokości dźwięku, „Res Facta Nova" 1994 t. 1(10), s. 12-16.

${ }^{24} \mathrm{O}$ studiach Mycielskiego nad „dziełkiem Eimerta” wspomina Iwona Lindstedt w monografii Dodekafonia i serializm..., op. cit., s. 289.

${ }^{25}$ Por. B. Mielcarek-Krzyżanowska, II Symfonia Zygmunta Mycielskiego: dzieło-manifest, [w:] Człowiek, myśl, muzyka..., op. cit., s. $106-113$.
Symboliczne znaczenie tych współbrzmień zaznaczył Mycielski w jednym z zapisów z 1982 roku:

Kwinty, kwarty, oktawy, fascynacja interwałami czystymi. Są to jakieś „wieczne” brzmienia. Intuicyjnie (?) w chorale gregoriańskim brzmiące, w tym, co jeszcze nie jest sztuką, a jest muzyką ${ }^{26}$.

Ich wyeksponowanie, wraz z charakterystyczną dla tego twórcy surowością środków, szczególnie wyrazistą w kompozycjach o charakterze religijnym, jest zabiegiem świadomym, co potwierdzają m.in. słowa o konieczności ograniczenia zewnętrznych efektów, patosu i nowatorstwa na rzecz powagi i prostoty ${ }^{27}$. Można oczywiście zastanawiać się nad zasadnością tak dalece posuniętego ascetyzmu, jednak pamiętać należy, że to świadoma decyzja twórcza; że z całego spektrum możliwości kompozytor pozostawia oszczędne, pozornie bezbarwne środki, że ów filtr wystawienie niejako poza nawias zainteresowań Mycielskiego komplikacji i zbędnych efektów - pozwala na pozostawienie tych elementów, które uznać można za esencję, istotę, trzon jego wypowiedzi artystycznej. I wydaje się, że nie jest to sztuczne kreowanie sfery sacrum, że stosowane zabiegi i mechanizmy służą wydobyciu treści i emocji opracowywanych tekstów, a w tworzonej narracji wyczuwa się autentyczność, prawdę i skromność.

Dwuczęściowa struktura fragmentu misterium Juliusza Słowackiego znalazła odzwierciedlenie w rozczłonkowaniu kompozycji Zygmunta Mycielskiego na dwa ogniwa domknięte swoistą codą, w której twórca dodał do tekstu wieszcza słowa „Pan Światłość, pokój nad całym stworzeniem". Każde z ogniw poprzedzone jest instrumentalnym wstępem nabierającym charakteru ekspresyjnego wprowadzenia w nastrój następującego po nim segmentu wokalno-instrumentalnego (por. ilustr. 3).

${ }^{26}$ Cyt. za: Z. Mycielski, Niby-dziennik ostatni..., op. cit., s. 163 (zapis z dnia 4 II 1982).

27 „Język muzyczny [... mszy], który w dużym stopniu nawiązuje do chorału gregoriańskiego, jest językiem poważnym, unika efektów [...] Starałem się zawęzić paletę, żeby to było pisane alfabetem podstawowym, takim, jaki dają tradycyjne instrumenty [...] chciałem uniknąć dętego patosu. Sztuka jest potrzebą głębszą, a nie tylko jakąś emocją nowości, niespodzianki, zdziwienia...”; E. Markowska, Z. Mycielski, Dwie rozmowy, „Res Facta Nova” 1994 t. 1(10), s. 39. 


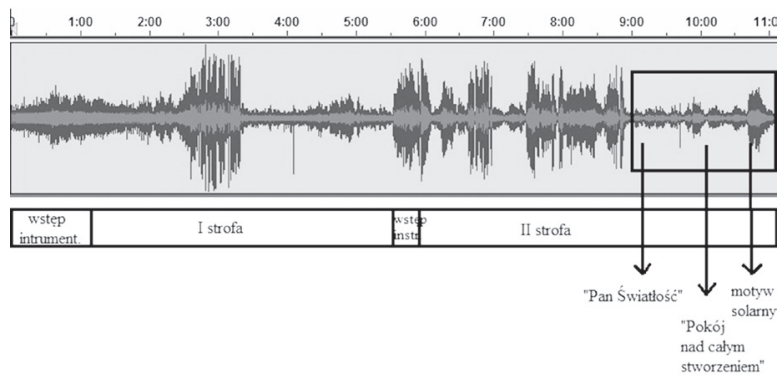

Ilustr. 1. Fragmenty Zygmunta Mycielskiego; spektrogram nagrania utrwalonego na płycie Polskich Nagrań Warszawska Jesień 1987. Kronika dźwiękowa nr 7 SX2582 28.

W ogniwie pierwszym, statycznym, muzyka wyłania się niemal z ciemności nocy. Inicjujący motyw klarnetu, eksponujący ruch sekund i tercji, wtapia się w subtelne brzmienie smyczków uzupełnione ciemnym brzmieniem fagotu. Centrum tonalnym instrumentalnego wstępu jest dźwięk $a$, opatrzony przez Mycielskiego w materiale prekompozycyjnym komentarzem "nuta wędrowna” (por. fot. 2). Od niego zaczynają niejako sączyć się kolejne motywy tworząc finezyjne tło, na którym niezwykle spokojnie („czysto, bez pizzicata” - jak nadmienia Mycielski w szkicach ${ }^{29}$ ) wprowadzane są kolejne wersy tekstu opisującego rozpromieniony świat. Melorecytacyjne pochody wyłącznie głosów męskich, rozjaśnianych smyczkami w wysokim rejestrze, stopniowo nabierają rozpędu, by ilustrować kolejne hiperboliczne obrazy (por. przykł. $1^{30}$ ). O ile materiał dźwiękowy wstępu „wypromieniowany” został z „nuty wędrownej” i - tym samym - scentralizowany wokół dźwięku $a$, ogniwo, w którym muzyka łączy się z tekstem, podporządkował kompozytor regułom systemu tablicowego. Kolejne dźwięki poszczególnych głosów chóru pochodzą z początkowej sekwencji pierwszego szeregu tablicy dodekafonicznej.

\footnotetext{
${ }^{28}$ Chór i Orkiestra Filharmonii Śląskiej w Katowicach, dyr. Karol Stryja.

${ }^{29}$ Rękopiśmienne szkice kompozycji z Archiwum Zygmunta Mycielskiego ze Zbiorów BN w Warszawie.

${ }^{30}$ Przykłady muzyczne pochodzą z rękopisu odnalezionego przez Beatę Bolesławską-Lewandowską w zbiorach Andrzeja Panufnika w Twickenham pod Londynem w 2020 roku. Autorka składa podziękowanie dr hab. Bolesławskiej-Lewandowskiej za udostępnienie partytury utworu.
}
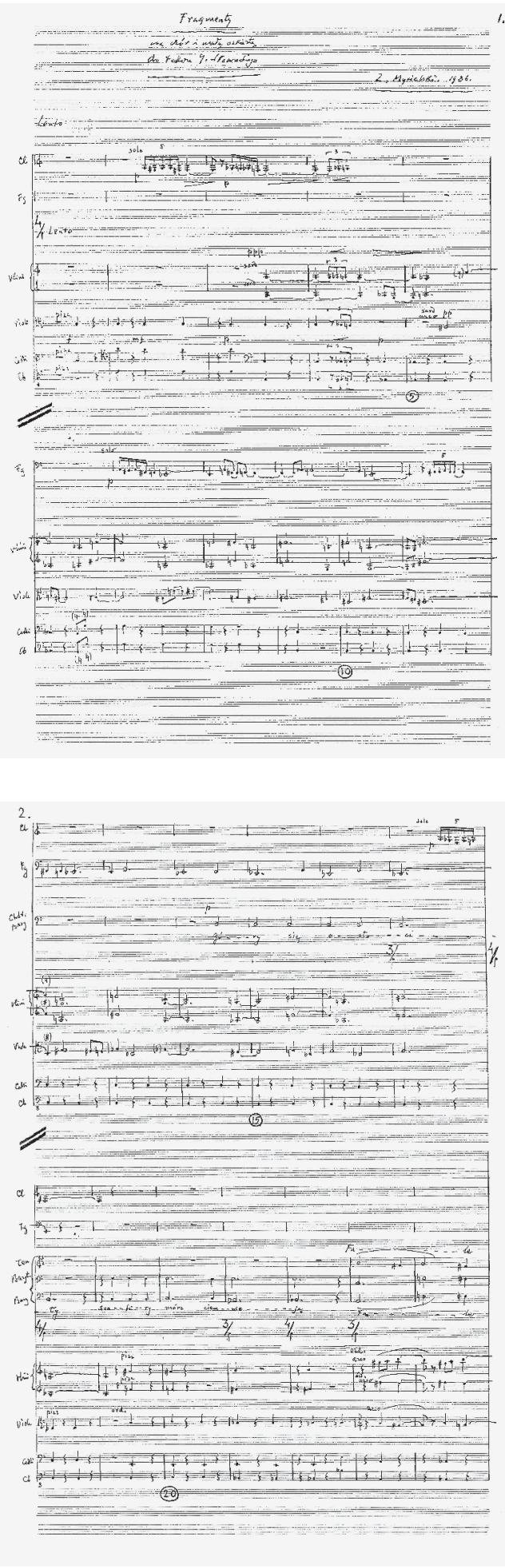

Przykł. 1: Zygmunt Mycielski, Fragmenty na chór i małą orkiestrę do tekstu J. Słowackiego, t. 1-24. 
Nokturnowy charakter tego segmentu, osiągnięty zestrojeniem spokojnego tempa (Lento) z niskim poziomem dynamicznym, ciemną barwą oraz niespieszną melodeklamacją zostaje ożywiony w środkowym fragmencie (por. spektrogram, 2:30-3:20), gdy muzyka staje się nośnikiem tekstu traktującego o wrącym na ognistej pianie okręcie. Kontrast dynamiczny (crescendo i forte), wzmożenie ruchu poprzez rozdrobnienie wartości rytmicznych oraz poszerzenie pola fakturalnego intensyfikują symboliczne przesłanie tego obrazu. W Noc Narodzenia na świat przyszedł Zbawiciel; i to Jego przyjście obrazuje korab-arka, która za czasów Noego umożliwiła przetrwanie rodzaju ludzkiego.

Kolejne, tym razem dynamiczne ogniwo Fragmentów rozpoczyna, jak już wzmiankowano, instrumentalny wstęp gwałtownie przerwany pojawieniem się głosów żeńskich, wzywających pasterzy, „rannych ludzi", by z muzyką wyruszyli powitać Dziecko (kulminacja tego odcinka na słowach „Pan przyszedł [...] chodźmy”). I kiedy, wraz z rozdrobnieniem wartości rytmicznych wynikającym $\mathrm{z}$ zachowania naturalnego rytmu słów, pojawia się wezwanie skierowane ku „rannym ludziom”, Mycielski gwałtownie zatrzymuje ruch, powtarza słowa, zaopatrując je w coraz bardziej kunsztowne figury muzyczne, uwypuklając znaczenie Narodzenia. W stosunku do początkowego zamiaru uzupełnia kompozytor wybrane strofy $\mathrm{z}$ misterium Słowackiego o błogosławieństwo: „Pokój nad całym stworzeniem". I choć owa szczególnego rodzaju coda rozgrywa się niemal w ciszy (partie chóralne, przerwane recytatywem waltorni opartym na sekwencji szóstego szeregu, wykonywane są a cappella), wydaje się, że to właśnie ona stanowi kluczowy moment całej kompozycji. Podobne intuicje we wspomnieniu opublikowanym na łamach „Res Facta Nova” po śmierci Zygmunta Mycielskiego wyraził Michał Bristiger, odnosząc się do tego fragmentu w niezwykle poetycki sposób:

Teraz słucham, jak muzyka kończy się słowem Świa-tło-ś-ć i muzyczną figurą, jaka pojawiła się zarazem na początku utworu, na ciemnym tle, kiedy jeszcze nie wiadomo, co z niej wyniknie, a przy końcu już się spełnia. To słowo zaczyna świecić, a zawiera w sobie i świat, i jego tło, i tę swoją - mówi Miłosz - «błazeńską czapkę» z ś i ć, jaką język polski nakłada na słowa uroczyste, a którą Zygmunt ostatnim swym gestem strącił ze słowa, pozwalając mu w sposób wolny promienieć. Odrywa się głos fletu, idzie cicho i spokojnie w górę, aż osiągnie, w harmonii $z$ ostatnim akordem swój ostatni dźwięk, aż rozpłynie się w pauzie - bez fermaty, pianissimo i ritenuto a piacere. Wsłuchuję się w tę ciszę, tę chwilę odejścia, ten moment rozmowy, pragnąc szepnąć: „Dobranoc, mój książę”31.

Ten symboliczny, solarny motyw (por. przykł. 2), jako „światłość wiekuista” wybrzmiewał także w nieco wcześniejszym, chóralnym Wiecznym odpoczywaniu, w quasi-requiem pisanym dla chóru w rodzinnej Wiśniowej, a jednocześnie także dla siebie...

VI. We Fragmentach zaobserwować można elementy, jakie w swej koncepcji duchowości muzyki wyodrębnił Bohdan Pociej (religijny temat, poruszenie i przeniknięcie $)^{32}$. Bezdyskusyjną kwestią jest oczywiście podjęty przez Mycielskiego temat nawiązujący do jednej z największych tajemnic chrześcijaństwa - ,wyjścia Boga na spotkanie z człowiekiem", by przywołać słowa biskupa Karola Wojtyły z 1968 roku $^{33}$. Decyzja o umuzycznieniu tekstu Słowackiego wpłynęła na sposób ukształtowania materiału prekompozycyjnego i odpowiednie jego zadysponowanie, ze szczególnym uwzględnieniem tradycyjnych symboli muzycznych, wprowadzając Fragmenty w przestrzeń religijnego poruszenia. Stadium religijnego przeniknięcia $\mathrm{z}$ kolei odczytywane może być z perspektywy skupienia osiągniętego na drodze redukcji oraz wyrażenia za pomocą dźwięków przejścia od ciemności do światła.

Przypisywaną ostatnim kompozycjom Mycielskiego metafizykę i duchową dojrzałość, osiągane spójnością koncepcji i wyjątkowym skupieniem, przenieść można także na wieńczące jego drogę twórczą Fragmenty. Przywołując inwariantny model faz twórczości zaproponowany przez Mieczysława Tomaszewskie$\mathrm{go}^{34}$, przedstawiony utwór można by zakwalifikować do kręgu dzieł ostatnich, naznaczonych charakterem solilokwialnym. Podjęty przez Słowackiego wątek

\footnotetext{
${ }_{31}$ M. Bristiger, Zygmunt Mycielski [wspomnienie], „Res Facta Nova" 1994 t. 1(10), s. 9.

32 B. Pociej, Stadia muzycznej duchowości. Trzy wykłady, Katowice 2009.

33 [Hasło:] Cud, [w:] K. Rahner, H. Vorgrimler, Mały słownik teologiczny, Warszawa 1987, s. 67-68.

${ }^{34}$ M. Tomaszewski, Droga twórcza, jej progi $i$ fazy, przemiany i fiksacje, [w:] Dzieło muzyczne i jego konteksty (5), red. A. Nowak, Bydgoszcz 2009, s. 9-20.
} 
Pastorałka dramatyczna Juliusza Słowackiego i jej muzyczna interpretacja
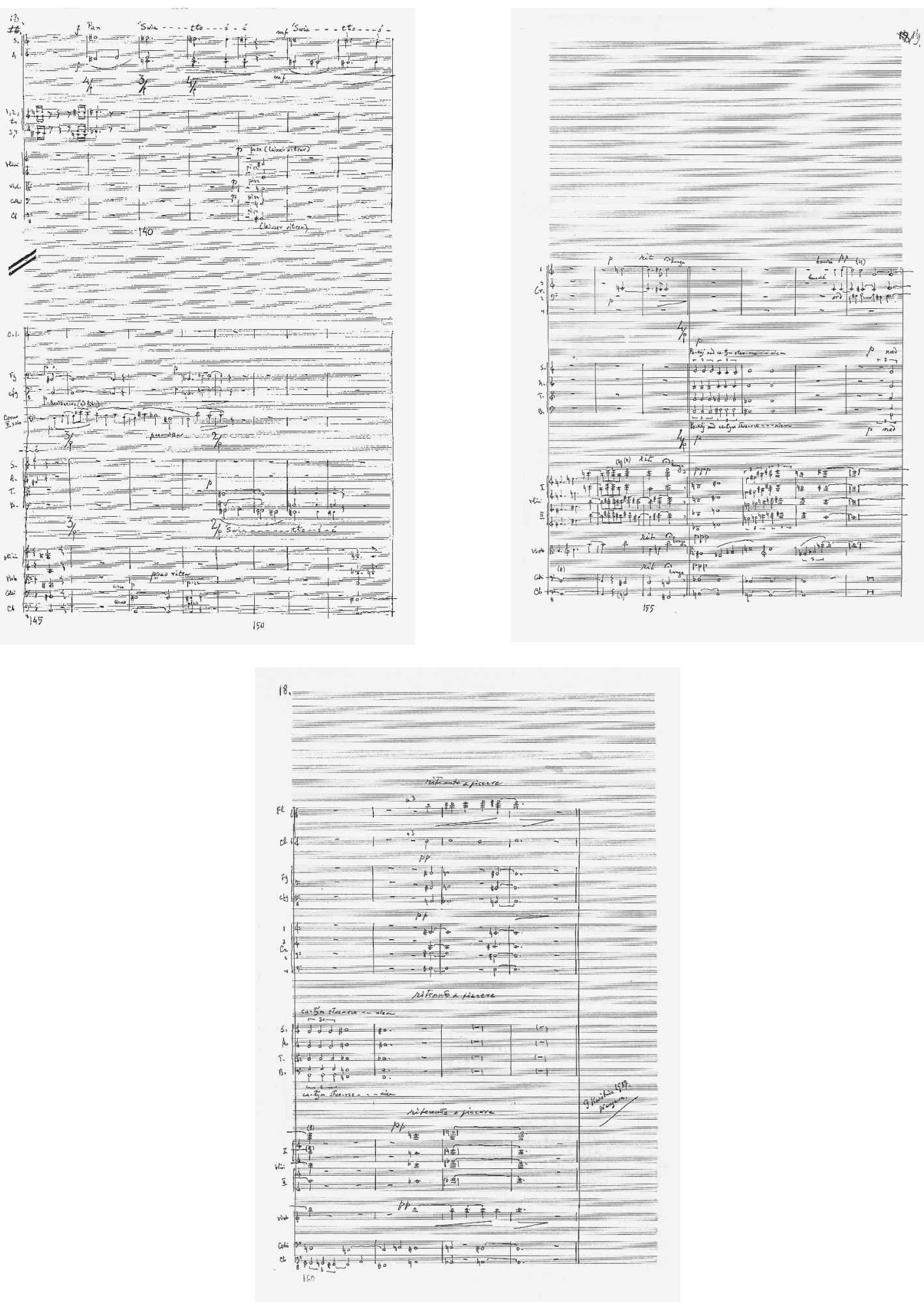

Przykł. 2: Zygmunt Mycielski, Fragmenty na chór i małą orkiestrę do tekstu J. Słowackiego, t. 149-164. 
Bożego Narodzenia cechuje szczególna świadomość bliskości Stwórcy... Wobec śmierci Mycielskiego cztery miesiące po skomponowaniu Fragmentów, symbolika utworu nabiera szczególnego znaczenia...

\section{BIBLIOGRAFIA}

Bilińska Stefania, Chrystus i chrześcijaństwo w twórczości Słowackiego epoki mistycznej, Księgarnia i Drukarnia Zygmunta Jelenia, Tarnów 1929.

Bristiger Michał, Zygmunt Mycielski [wspomnienie], „Res Facta Nova” 1994 t. 1(10), s. 9.

Chybiński Adolf, Juliusz Słowacki w muzyce polskiej, „Pamiętnik Literacki” 1909 t. 8 nr 1/4, s. 225-228.

Człowiek nigdy nie jest sam. Rozmowa $\mathrm{z}$ ks. Janem Twardowskim w Warszawie (rozmawiał Andrzej Szypuła), „Kamerton" 1993 t. 3(14), s. 23.

Gubrynowicz Bronisław, Z nieznanych rękopisów po Słowackim, „Pamiętnik Literacki” 1909 t. 8 nr 1/4, s. 234-244.

Gutkowska Barbara, „Chciałbym jeszcze kogoś uzdrowić, coś uzdrowić, naprawić. Ale jest już za późno”. Fenomen dzienników Zygmunta Mycielskiego, [w:] Człowiek, myśl, muzyka. Wokół postaci i twórczości Zygmunta Mycielskiego, red. Beata Bolesławska-Lewandowska, Barbara Mielcarek -Krzyżanowska, Grzegorz Oliwa, Wydawnictwo Uniwersytetu Rzeszowskiego, Rzeszów 2019, s. 17-31.

Koszewska Anna, Credo estetyczne Zygmunta Mycielskiego. Próba rekonstrukcji systemu, [w:] Krytyka muzyczna. Teoria, historia, wspótczesność, red. Michał Bristiger, Rafał Ciesielski, Barbara Literska, Jolanta Guzy-Pasiak, Oficyna Wydawnicza Uniwersytetu Zielonogórskiego, Zielona Góra 2009, s. 175-180.

Lindstedt Iwona, Dodekafonia i serializm w twórczości kompozytorów polskich XX wieku, Polihymnia, Lublin 2001.

Ławrynkowicz Marta, Nowe wydanie krytyczne Poematów Juliusza Słowackiego, „Sztuka Edycji” 2011 t. 1, s. 88-91.

Markowska Elżbieta, Mycielski Zygmunt, Dwie rozmowy, „Res Facta Nova” 1994 t. 1(10), s. 37-41.

Mielcarek-Krzyżanowska Barbara, „U Bacha ani jedna nuta nie spada z nieba". Zygmunt Mycielski a twórczość Jana Sebastiana Bacha, [w:] Dzieło muzyczne wobec przeszłości i wspótczesności, red. Anna Nowak i Barbara Mielcarek-Krzyżanowska, Akademia Muzyczna im. Feliksa Nowowiejskiego, Bydgoszcz 2020, s. 307-324.

Mielcarek-Krzyżanowska Barbara, II Symfonia Zygmunta Mycielskiego: dzieło-manifest, [w:] Człowiek, myśl, muzyka.
Wokó postaci i twórczości Zygmunta Mycielskiego, red. Beata Bolesławska-Lewandowska, Barbara Mielcarek-Krzyżanowska, Grzegorz Oliwa, Wydawnictwo Uniwersytetu Rzeszowskiego, Rzeszów 2019, s. 106-113.

Mycielski Zygmunt, Dziennik 1950-1959, Warszawa 1999.

Mycielski Zygmunt, Jeszcze o wyborach wysokości dźwięku, „Res Facta Nova” 1994 t. 1(10), s. 12-16.

Mycielski Zygmunt, Niby-dziennik ostatni 1981-1987, Wydawnictwo Iskry, Warszawa 2012.

Mycielski Zygmunt, Szkice i wspomnienia, red. Paweł Kądziela, Biblioteka „Więzi”, Warszawa 1999.

Pigoń Stanisław, Nowe wydanie zbiorowe Słowackiego, „Pamiętnik Literacki” 1950 t. 39, s. 361-401.

Pociej Bohdan, Stadia muzycznej duchowości. Trzy wykłady, Akademia Muzyczna im. Karola Szymanowskiego, Katowice 2009.

Rahner Karl, Vorgrimler Herbert, [hasło:] Cud, [w:] Karl Rahner, Herbert Vorgrimler, Mały słownik teologiczny, przeł. Tadeusz Mieszkowski, Paweł Pachciarek, Instytut Wydawniczy PAX, Warszawa 1987, s. 67-68.

Seweryn Agata, Poezja „nutami niesiona”. O muzycznej recepcji twórczości Juliusza Słowackiego, Instytut Badań Literackich PAN, Warszawa 2008.

Tomaszewski Mieczysław, Droga twórcza, jej progi i fazy, przemiany i fiksacje, [w:] Dzieło muzyczne i jego konteksty (5), red. Anna Nowak, Akademia Muzyczna im. Feliksa Nowowiejskiego, Bydgoszcz 2009, s. 9-20.

Zwierzyński Leszek, Egzystencja i eschatologia. Genezyjska wyobraźnia Słowackiego, Wydawnictwo Uniwersytetu Śląskiego, Katowice 2008.

Zygmunt Mycielski - Andrzej Panufnik. Korespondencja. Część I: lata 1949-1969, opracowanie, wstęp i komentarze Beata Bolesławska-Lewandowska, Instytut Sztuki PAN, Warszawa 2017.

Za udzielenie zgody na publikację przykładów muzycznych autorka składa podziękowanie pani Zofii Mycielskiej-Golik.

Materiały rękopiśmienne pochodzą z archiwum Zygmunta Mycielskiego znajdującego się w Bibliotece Narodowej. 


\title{
SUMMARY
}

\section{Barbara Mielcarek-Krzyżanowska}

\section{Drama Pastorale by Juliusz Słowacki} and its Musical Interpretation in Fragmenty by Zygmunt Mycielski

\begin{abstract}
Zygmunt Mycielski's final work, Fragmenty to words by Juliusz Słowacki (1987) belongs to the collection of religious works which crown the creative path of the author of Postludia. Fragmenty were written on the basis of a rigorous, individual method of composing using twelve notes an array system devised by him towards the end of the 1950s which from that time consistently accompanied his creative undertakings. The austerity of technique achieved by limiting external effects, particularly apparent in Mycielski's religious compositions (alongside Fragmenty one should mention here above all Trzy psalmy and the mass Liturgia sacra), results from the desire to reject pathos in favour of gravity and simplicity. This conscious creative decision means that the devices used serve to bring out the meaning and the emotion in Słowacki's text, and in the created narration one perceives authenticity, truth and modesty. Fragmenty may be interpreted as a special kind of testament, Mycielski's confession of faith, and the shades of sacrality discovered in it - the stages of musical spirituality according to Bohdan Pociej's conception, support this supposition.
\end{abstract}

\section{Keywords}

Zygmunt Mycielski, Juliusz Słowacki, sacrum in music, cantata-oratorio works, late style 